\title{
Peningkatan Kemampuan Guru Dalam PemanfaAtan Teknologi Informasi Pada Kegiatan Pembelajaran
}

\author{
${ }^{1}$ R. Ceha, ${ }^{2}$ Endang Prasetyaningsih, ${ }^{3}$ Iyan Bachtiar, ${ }^{4}$ Agus Nana S. \\ 1,2,3,4 Jurusan Teknik Industri Universitas Islam Bandung, Jl. Tamansari No. 1 Bandung 40116 \\ e-mail: ${ }^{1}$ rceha@yahoo.com, ${ }^{2}$ endangpras@gmail.com, , ${ }^{4}$ iyanbachtiar1806@gmail.com, \\ ${ }^{4}$ agusns1967@yahoo.co.id.
}

\begin{abstract}
Abstrak. Dalam upaya peningkatan mutu mengajar dan mutu pembelajaran di era globalisasi, guru sebaiknya menguasai program komputer, agar dapat memanfaatkan teknologi yang telah tersedia dan untuk memudahkan dalam mengajar. Guru hendaknya dapat menggunakan peralatan yang lebih ekonomis, efisien, dan mampu dimiliki oleh sekolah, tidak menolak digunakannya peralatan teknologi modern yang relevan dengan tuntutan masyarakat dan perkembangan zaman, serta mempunyai berbagai keterampilan yang mendukung tugasnya dalam mengajar. Salah satu keterampilan tersebut adalah bagaimana seorang guru dapat menggunakan media pembelajaran (Syaiful Bahri, 2006). Guru dapat membuat kreasi dan variasi media interaktif, pembuatan $C D$ pembelajaran interaktif, powerpoint, dan dengan media komputer. Masalah utama yang dihadapi mitra saat ini adalah kemampuan guru dalam pemanfaatan IT atau ICT untuk kegiatan pembelajaran belum merata. Selain itu juga masih adanya kesenjangan literasi TIK antar wilayah di satu sisi dan perkembangan internet yang ju ga membawa da mpak negatif terhadap nilai dan norma masyarakat sehingga perlu dilakukan upaya secara aktif dari semua stakeholder sekolah dalam peningkatan kualitas pembelajaran dengan memanfaatkan teknologi informasi dan komunikasi. Kegiatan Pengabdian kepada masyarakat yang diusulkan bertujuan untuk meningkatkan pengetahuan guru mengenai pemanfaatan teknologi informasi dan komunikasi pada kegiatan pembelajaran, meningkatkan kemampuan guru untuk membuat bahan ajar pemanfaatan teknologi informasi dan komunik asi sehing ga dapat mengoptimalkan potensi yang ada di sekolah mitra dalam pemanfaatan Teknologi Informasi untuk peningkatan kualitas pembelajaran
\end{abstract}

Kata Kunci : Teknologi informasi dan komunikasi (TIK), kualitas pembelajaran

\section{Pendahuluan}

Era globalisasi yang semakin berkembang menuntut kemampuan semua bangsa untuk ikut bersaing dengan negara lain, termasuk kesiapan sumber daya manusia yang tentu saja harus disiapkan sejak dini dengan berbagai upaya dan sesuai dengan perkembangan zaman. Seorang futuristik kenamaan dari Austria dalam bukunya Megatrends 2000, Jonn Naisbitt, telah memprediksi bahwa milennium ke-2 akan didominasi sebagai era reformasi (Isdjoni, 2008). Ini berarti bahwa suatu bangsa atau negara yang unggul dalam teknologi informasi maka akan unggul pula dalam mendominasi dunia.

Untuk dapat menghadapi tantangan global tersebut diperlukan upaya untuk mempersiapkan sumber daya manusia yang berkualitas. Ketersediaan sumber daya alam yang melimpah dan beraneka ragam tidak akan memberikan dampak besar terhadap kesejahteraan masyarakat apabila tidak ada tenaga-tenaga ahli yang mampu mengolah sumber daya alam tersebut. Dengan adanya fakta tersebut maka bangsa Indonesia dituntut untuk mampu meningkatkan kualitas sumber daya manusia, yang salah satunya adalah dengan meningkatkan mutu pendidikan. 
Upaya penting untuk meningkatkan mutu pendidikan adalah dengan mengembangkan teknologi pendidikan dan pembelajaran. Pendayagunaan teknologi pendidikan (Educatian Technology) atau berbagai istilah yang mereka gunakan: Teknologi untuk Pendidikan (Technology for Education), Teknologi Informasi (Information Technology/IT) atau Teknologi Komunikasi dan Informasi (Information and Communication Technology/ICT) diyakini sebagai salah satu cara strategis mengatasi masalah tersebut (Dewi, 2007). Pentingnya pemanfaatan teknologi informasi dan komunikasi di bidang pendidikan juga ditekankan oleh Negara-negara Asia Tenggara. Upaya peningkatan mutu pendidikan lebih difokuskan kepada aparat pendidikan (guru, kepala sekolah, tenaga administrasi) dan komite sekolah. Bentuk upaya yang dilakukan ini bisa melalui pendidikan pelatihan, TOT, workshop, seminar dan lokakarya pembinaan kelembagaan pendidikan.

Guru adalah pendidik professional dengan tugas utama mendidik, mengajar, membimbing, mengarahkan, melatih, menilai, dan mengevaluasi peserta didik pada pendidikan anak usia dini, jalur pendidikan formal, pendidikan dasar, dan pendidikan menengah.Dalam upaya peningkatan mutu mengajar dan mutu pembelajaran di era globalisasi, guru sebaiknya menguasai program komputer, agar dapat memanfaatkan teknologi yang telah tersedia dan untuk memudahkan dalam mengajar. Guru hendaknya dapat menggunakan peralatan yang lebih ekonomis, efisien, dan mampu dimiliki oleh sekolah serta tidak menolak digunakannya peralatan teknologi modern yang relevan dengan tuntutan masyarakat dan perkembangan zaman. Seorang guru dituntut untuk mempunyai berbagai keterampilan yang mendukung tugasnya dalam mengajar. Salah satu keterampilan tersebut adalah bagaimana seorang guru dapat menggunakan media pembelajaran (Syaiful Bahri, 2006). Guru dapat membuat kreasi dan variasi media interaktif, pembuatan $\mathrm{CD}$ pembelajaran interaktif, powerpoint, dan dengan media komputer.

Pengimplementasian Teknologi Informasi dan komunikasi (TIK) mencakup sumber daya manusia, infrastruktur, hardware, dan software. Hambatan dalam pengimplementasian di sekolah antara lain: jumlah tenaga pengelola yang memiliki kompetensi di bidang teknologi informasi belum mencukupi, belum semua sekolah memiliki infrastruktur yang mendukung, belum semua sekolah memiliki hardware lengkap baik secara kualitas maupun kuantitas, dan software original mahal (Herman Dwi Surjono dan Abdul Gafur, 2010). Jika terjadi hambatan tersebut berarti sebagian dari guru SMA di wilayah Banjarsari dan sekitarnya belum mengimplementasikan TIK dalam pembelajaran mereka sehingga pembelajaran masih bersifat konvensional dan kurang bervariasi. Pembelajaran yang konvensional dan kurang bervariasi akan membuat siswa bosan belajar serta kurang termotivasi untuk mengikuti proses pembelajaran di sekolah yang akhirnya akan berpengaruh pada kualitas pembelajaran dan prestasi siswa. Untuk itu, perlu dilakukan upaya-upaya yang dilakukan untuk mengatasi kendala-kendala tersebut sehingga pemanfaatan Teknologi Informasi dan Komunikasi di sekolah menjadi lebih optimal terutama untuk sekolah-sekolah di kota kecil seperti daerah Banjarsari dan sekitarnya.

Kegiatan Pengabdian Masyarakat ini merupakan bentuk peran aktif perguruan tinggi sebagai "pengguna" lulusan sekolah menengah atas untuk meningkatkan kemampuan guru dalam memanfaatkan teknologi informasi dan komunikasi yang diharapkan akan berdampak pada kualitas pembelajaran dan kualitas siswa lulusan. Dengan demikian, kesenjangan penguasaan teknologi informasi bagi siswa-siswa 
lulusan dari sekolah di wilayah sekitar mitra dengan siswa-siswa dari kota-kota besar dapat diperkecil.

\section{Metode Penerapan IPTEKS}

Solusi yang ditawarkan untuk menyelesaikan masalah dengan memanfaatkan potensi yang ada adalah memberikan pelatihan dan pendampingan pemanfaatan teknologi informasi dan komunikasi dalam kegiatan pembelajaran di sekolah. Pelatihan yang diberikan meliputi mencari bahan ajar dan bahan penelitian di internet, juga pelatihan mengenai bagaimana memanfaatkan situs-situs atau aplikasi-aplikasi open source yang ada untuk pembelajaran. Kegiatan atau langkah-langkah yang akan dilakukan dalam peningkatan kemampuan guru untuk memanfaatkan teknologi informasi adalah sebagai berikut :

1. Studi pendahuluan dan identifikasi kegiatan yang dibutuhkan, mencakup identifikasi lebih lengkap mengenai kondisi sekolah mitra dan sekolah-sekolah di wilayah sekitar sekolah mitra, kondisi pemanfaatan teknologi informasi yang selama ini dilakukan, identifikasi sarana penunjang yang dapat dimanfaatkan yang ada di sekolah, identifikasi pelatihan-pelatihan yang telah diberikan kepada guru-guru berkaitan dengan penggunaan teknologi informasi.

2. Menyusun rencana pelaksanaan kegiatan berdasarkan kesepakatan dengan mitra PKM sehingga diharapkan seluruh kegiatan yang diusulkan dapat terlaksana dengan baik sesuai dengan tujuan yang ingin dicapai dan waktu yang ditentukan.

3. Identifikasi pelatihan yang diperluka mitra dalam hal pemanfaatan teknologi informasi untuk meningkatkan kualitas pembelajaran dan metoda pelatihan yang akan dilakukan dan koordinasi dengan sekolah mitra untuk waktu pelaksaan dan peserta. Kebutuhan dikhususkan pada kebutuhan pelatihan tidak pada kebutuhan sarana dan prasarana.

4. Melaksanakan Pelatihan di sekolah mitra dengan peserta guru-guru dari sekolah mitra dan dari sekolah-sekolah di wilayah sekitar sekolah mitra bertujuan untuk peningkatan kemampuan guru dalam memanfaatkan teknologi informasi untuk proses pembelajaran.

5. Melakukan Pendampingan untuk memastikan bahwa kegiatan pelatihan yang diberikan dapat memberikan dampak pada pemanfaatan teknologi informasi untuk proses pembelajaran.

6. Monitoring dan Evaluasi mengenai hasil kegiatan yang telah dilakukan dan mengidentifikasi kendala-kendala yang dihadapi serta upaya untuk menyelesaikannya termasuk juga mengidentifikasi peluang-peluang untuk perluasan kegiatan yang lainnya. 


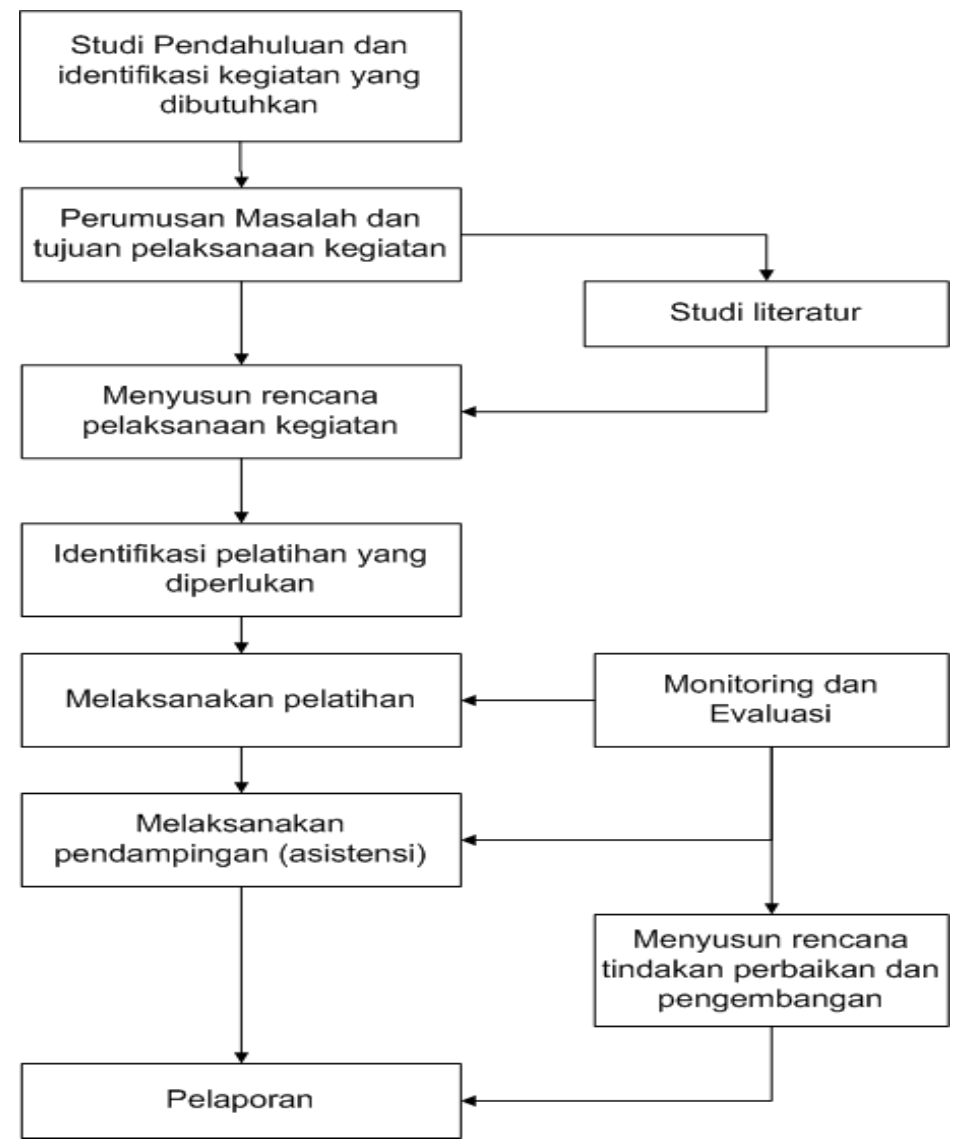

Gambar 1. Tahapan Pelaksanaan Kegiatan

\section{Hasil yang Dicapai}

\subsection{Tahap Persiapan}

Tahap persiapan merupakan kegiatan sebelum pelaksanaan PKM yang meliputi sosialisasi mengenai kegiatan PKM yang akan dilaksanakan, melakukan studi pendahuluan, serta berkoordinasi dengan sekolah mitra untuk pelaksanaan PKM. Studi pendahuluan dilakukan untuk mengetahui dengan lebih lengkap mengenai kondisi mitra PKM. Pada tahap ini, tim melakukan pengamatan mengenai kondisi penguasaan teknologi informasi di lingkungan guru-guru pada sekolah mitra dan sekolah yang lain di sekitar sekolah mitra, identifikasi pemanfaatan teknologi informasi dalam pembelajaran yang telah dilakukan, serta identifikasi tingkat pengetahuan mitra mengenai pemanfaatan IT dalam pembelajaran terutama penggunaan aplikasi-aplikasi open source untuk pembelajaran. Hasil pengamatan atau studi menunjukkan bahwa :

- Sebagian besar guru di sekolah mitra merupakan guru senior dengan tingkat penguasaan teknologi informasi yang tidak terlalu bagus. Dalam penggunaan komputer untuk pembelajaran, aplikasi yang biasa digunakan masih terbatas pada aplikasi Microsoft word dan powerpoint sederhana.

- Guru-guru di sekolah mitra belum mendapat pelatihan mengenai pemanfaatan teknologi informasi untuk proses pembelajaran. Pelatihan yang telah diterima adalah pelatihan-pelatihan yang sifatnya pemanfaatan komputer untuk keperluan administrasi seperti pelatihan penggunaan aplikasi untuk guru Bimbingan Karir. 
- Fasilitas pendukung terutama jaringan internet di sekolah mitra kurang memadai. Pihak sekolah mengalami kesulitan dalam pemeliharaan fasilitas yang telah ada karena berbagai keterbatasan keuangan dan keterbatasan sumber daya manusia.

- Sebagian besar guru dan siswa pada sekolah mitra telah memiliki gadget teknologi tinggi seperti smartphone dan Ipad, akan tetapi pemanfaatannya untuk pembelajaran masih sangat rendah.

Kegiatan lain yang telah dilaksanakan pada tahap persiapan adalah melakukan koordinasi dengan pihak sekolah mitra untuk membuat perencanaan pelaksaan kegiatan PKM. Pada kegiatan koordinasi ini disepakati bahwa yang menjadi koordinator kegiatan PKM di pihak sekolah mitra adalah Bapak Yosep Setiawan, S.Pd., M.Pd.

\subsection{Tahap Pelaksanaan}

\section{A. Penyusunan rencana Pelaksanaan PKM}

Rencana pelaksanaan PKM disusun berdasarkan kesepakatan antara tim pelaksana PKM dengan koordinator dari sekolah mitra. Setelah dilakukan beberapa kali pertemuan dan komunikasi melalui telepon dan e mail, maka disepakati bahwa akan dilaksanakan kegiatan Workshop mengenai Pemanfaatan Teknologi Informasi pada Kegiatan Pembelajaran dengan waktu pelaksanaan Workshop disesuaikan dengan kegiatan tim di Unisba dengan kegiatan akademik pihak sekolah mitra. Selain jenis kegiatan yang akan dilaksanakan, pada tahap ini juga dibuat kesepakatan mengenai waktu pelaksanaan, peserta yang akan diundang selain dari sekolah mitra, serta pembagian tugas antara tim pelaksana PKM dari Unisba dengan tim dari sekolah mitra.

\section{B. Melakukan Pelatihan}

Berdasarkan rencana yang telah dibuat pada tahap sebelumnya, pelatihan atau workshop dilakukan pada tanggal 18 April 2015 bertempat di SMAN 1 Banjarsari. Peserta pelatihan berjumlah kurang lebih 50 orang guru-guru sekolah mitra dan guruguru SMA/SMK di sekitar sekolah mitra. Sekolah yang mengirimkan perwakilannya untuk mengikuti workshop berjumlah 12 sekolah yang berasal dari Banjarsari, Banjar, Cisaga, Padaherang, Lakbok, dan Mangunharja. Berkaitan dengan peserta workshop, sebenarnya antusiasme para guru untuk mengikuti kegiatan workshop sangat tinggi akan tetapi karena keterbatasan sumber daya yang dimiliki oleh tim pengabdi maka tim bekerjasama dengan koordinator di sekolah mitra membatasi jumlah peserta sekitar 50 orang. Koordinator kegiatan di sekolah mitra sangat membantu tim dalam melaksanakan PKM ini.

Materi yang diberikan pada kegiatan workshop adalah materi mengenai bagaimana trend kegiatan belajar mengajar di dunia pendidikan saat ini telah berubah sejalan dengan perkembangan teknologi informasi dan internet (Blended Teaching The Next Generation of Education), materi mengenai hal-hal yang mendukung keberhasilan kegiatan pembelajaran di sekolah (Efektifitas Pembelajaran), serta materi mengenai open source yang banyak tersedia dan praktek bagaimana memanfaatkannya untuk pembelajaran (Pemanfaatan Aplikasi Open Source dan Internet untuk Pembelajaran). Pada akhir sesi Workshop, peserta memberikan umpan balik dengan memberikan penilaian mengenai kegiatan yang dilakukan. Beberapa hal yang menjadi catatan bagi tim dan semua peserta adalah sebagai berikut : 
- Semua peserta sepakat bahwa workshop yang diberikan memberikan wawasan baru dalam pemanfaatan teknologi untuk pembelajaran. Para guru peserta workshop meminta untuk dilakukan pelatihan dengan jangka waktu lebih lama dan kegitan praktek yang lebih banyak karena peserta membutuhkan waktu lebih lama untuk belajar teknologi baru.

- Beberapa peserta mengeluhkan bahwa infrastruktur di sekolah tidak mendukung untuk pelaksanaan pembelajaran seperti yang dibahas pada workshop. Hal ini memberikan gambaran pada tim pelaksana PKM bahwa secara mendasar workshop yang dilakukan belum dapat mengubah mind set guru mengenai pemanfaatan IT untuk pembelajaran.

- Semua peserta menyatakan puas dengan pelaksanaan workshop dan meminta tim untuk memberikan pelatihan lain di masa yang akan datang.

\section{Melakukan Pendampingan}

Kegiatan pendampingan dilakukan sebagai tindak lanjut dari workshop yang telah diselenggarakan pada tahap sebelumnya. Kegiatan ini bertujuan untuk memastikan bahwa kegiatan pelatihan yang dilakukan dapat memberikan dampak pada pemanfaatan teknologi informasi untuk proses pembelajaran. Kegiatan pendampingan meliputi pemberian bantuan dan bimbingan pada proses penyiapan bahan ajar yang dibuat oleh guru dan hal-hal lain yang berkaitan dengan implementasi hasil pelatihan dengan cara melakukan komunikasi melalui e mail atau komunikasi telepon karena keterbatasan waktu dan biaya mengingat jarak sekolah mitra relatif jauh dari kampus Unisba. Akan tetapi, hasil tahap pendampingan belum sesuai dengan rencana yang dibuat. Beberapa hal yang diidentifikasi sebagai penyebab tidak optimalnya pelaksanaan tahap pendampingan adalah :

1. Keseriusan peserta pelatihan untuk mengimplementasikan hasil pelatihan atau workshop dinilai kurang sehingga fasilitas pendampingan yang disediakan tim pengabdi tidak dimanfaatkan secara optimal.

2. Penguasaan teknologi informasi dari peserta workshop (guru-guru SMA di sekitar sekolah mitra PKM) terutama berkaitan dengan internet kurang baik sehingga menghambat pelaksanaan rencana PKM yang telah dibuat oleh tim pengabdi.

3. Infrastruktur sekolah belum mendukung penuh sehingga peserta pelatihan kurang termotivasi untuk mengimplementasikan hasil pelatihan pada kegiatan pembelajaran.

4. Mengubah mind set peserta pelatihan memerlukan kegiatan yang lebih intensif dengan waktu yang lebih lama.

\section{Tahap Monitoring dan Evaluasi Program}

Pada tahap ini dilakukan evaluasi mengenai hasil kegiatan yang telah dilakukan dan identifikasi kendala-kendala yang dihadapi serta upaya untuk menyelesaikannya termasuk juga mengidentifikasi peluang-peluang untuk perluasan kegiatan yang lainnya. Secara umum, program atau kegiatan pengabdian kepada masyarakat ini dapat terlaksana dengan baik sesuai dengan rencana. Peserta pelatihan cukup antusias dan memberikan apresiasi sangat baik kepada tim terhadap pelaksanaan PKM ini. Tahapan kegiatan yang kurang optimal dilakukan adalah tahap pendampingan karena tidak ada peserta pelatihan yang melakukan bimbingan atau asistensi kepada tim pengabdi. 
Beberapa penyebab berkaitan dengan hal ini telah diuraikan pada uraian hasil pelaksanaan (penjelasan point $\mathrm{C}$.)

Beberapa kendala yang dihadapi tim pengabdi selama pelaksanaan program PKM adalah sebagai berikut :

- Pada kegiatan pelatihan, infrastruktur pada sekolah mitra kurang mendukung karena jaringan internet saat pelaksaan pelatihan sedang rusak. Untuk mengatasi hal tersebut, tim telah mempersiapkan mobile wifi untuk pelaksanaan praktek. Selain itu, penguasaan dan kemampuan peserta pelatihan dalam memanfaatkan teknologi informasi sangat beragam sehingga pelaksanaan praktek menjadi lebih lambat dari yang direncanakan.

- Beberapa guru mengeluhkan dukungan sekolah dan pemerintah yang kurang berkaitan dengan pemanfaatan IT pada proses pembelajaran sehingga motivasi untuk mengimplementasikan hasil pelatihan tidak begitu besar. Tim berusaha meyakinkan bahwa implementasi bias dilakukan secara bertahap dan dengan memanfaatkan fasilitas yang ada dan dimiliki sebagian besar siswa SMA.

\section{Kesimpulan dan Saran}

Tugas utama guru sebagai pendidik professional adalah mendidik, mengajar, membimbing, mengarahkan, melatih, menilai, dan mengevaluasi peserta didik pada pendidikan anak usia dini, jalur pendidikan formal, pendidikan dasar, dan pendidikan menengah. Seorang guru bertanggung jawab atas keberhasilan proses belajar mengajar. Dalam upaya peningkatan mutu mengajar dan mutu pembelajaran, guru sebaiknya menguasai program komputer, teknologi informasi dan komunikasi agar dapat memanfaatkan teknologi dalam kegiatan belajar mengajar. Guru hendaknya dapat menggunakan peralatan yang lebih ekonomis, efisien, dan mampu dimiliki oleh sekolah serta tidak menolak digunakannya peralatan teknologi modern yang relevan dengan tuntutan masyarakat dan perkembangan zaman. Untuk itu, berbagai kegiatan yang mendukung untuk peningkatan kemampuan guru dalam memanfaatkan teknologi informasi dan komunikasi dalam proses pembelajaran menjadi hal yang sangat dibutuhkan.

Kegiatan PKM ini dilakukan untuk memberikan sedikit kontribusi dalam peningkatan kemampuan guru dalam mengelola proses pembelajaran. Kegiatan ini tidak dapat berdiri sendiri dan masih membutuhkan kegiatan-kegiatan lanjutan agar dapat memberikan dampak yang signifikan bagi peningkatan kualitas pembelajaran dengan memanfaatkan teknologi informasi dan komunikasi.

\section{Daftar pustaka}

Dewi Salma Pradwiradilaga, dkk., 2007, Pendayagunaan Teknologi Pendidikan di Negara Tetangga, Mozaik Teknologi Pendidikan, Kencana Prenada Media Group, Jakarta

Fathul Wahid, Teknologi Informasi dan Pendidikan, 2007, Ardana media, Yogyakarta Isjoni, dkk., 2008, ICT Untuk Sekolah Unggul Pengintegrasian Teknologi Informasi dalam Pembelajaran, Pustaka Pelajar, Yogyakarta.

Syaiful Bahri Djamarah dan Aswan Zein, 2006, Strategi Belajar Mengajar, Rineka Cipta, Jakarta 
138 R. Ceha, et al.

Undang-Undang Republik Indonesia Nomor 20 Tahun 2003 tentang Sistem Pendidikan Nasional, 2007, Pustaka Pelajar, Yogyakarta.

Hamruni, 2009, Strategi dan Model-Model Pembelajaran Aktif Menyenangkan, Fakultas Tarbiyah UIN Sunan Kalijaga, Yogyakarta

http://www.maarif-u.or.id/Opini/tabid/175/articleType/ArticleView/articleId/153/

Pentingnya-Teknologi-dan-Informasi-dalam-Dunia-Pendidikan.aspx

diakses

9/12/201 